\title{
Seasonal Dynamics of the Microbial and Physicochemical Characteristics of Streams and Boreholes in Uzuakoli, Eastern Nigeria
}

\author{
Okezie Onyemaechi (Corresponding Author) \\ Department of Microbiology, University of Calabar, PMB 1115, Calabar, Cross River State, \\ Nigeria.E-mail: onyeokezie7@gmail.com or onyeokezie7@unical.edu.ng \\ Nwachukwu Ejikeme \\ Department of Microbiology, Micheal Okpara University of Agriculture Umudike, Nigeria.
}

Received: February 10, 2019

doi:10.5296/jbls.v10i2.14456
Accepted: March 3,, 2019

URL: https://doi.org/10.5296/jbls.v10i2.14456

\begin{abstract}
Water samples from twenty water sources (fifteen boreholes and five streams) in Uzuakoli, Nigeria were collected for the period of 6 months covering the dry and rainy seasons to assess the level of contamination. The Microbiological characteristics including heterotrophic counts, coliform counts and physicochemical parameters includes $\mathrm{pH}$, turbidity, dissolved oxygen, calcium, potassium, nitrate, magnesium and phosphate were evaluated using standard methods. The total Heterotrophic counts for the borehole during the dry and rainy season were $8.3 \times 10^{3}$ $\mathrm{cfu} / \mathrm{ml}$ and $10.8 \times 10^{4} \mathrm{cfu} / \mathrm{ml}$. The Heterotrophic counts for the stream were $12.7 \times 10^{4} \mathrm{cfu} / \mathrm{ml}$ and $17.8 \times 10^{6} \mathrm{cfu} / \mathrm{ml}$. The frequency of occurrence of the isolates are Staphylococcus aureus 63\% in borehole and $85 \%$ in streams, Pseudomonas aeruginosa $49 \%$ in boreholes and $95 \%$ in streams, Proteus sp 52\% in boreholes and $97 \%$ in streams, Streptococcus sp $46 \%$ in boreholes and $53 \%$ in streams, Enterobacter aerogenes $33 \%$ in boreholes and $63 \%$ in streams, Escherichia coli $16 \%$ in boreholes and $53 \%$ in streams and Salmonella sp no percentage in boreholes and $40 \%$ in streams. The result shows a significant difference at $(\mathrm{P} \leq 0.05)$ for the bacterial isolates. The physicochemical parameters of the borehole and stream water samples during the dry and rainy seasons were determined. The temperature ranged from $25^{\circ} \mathrm{C} 32^{\circ} \mathrm{C}$; $\mathrm{pH}$ ranged from 5.38 .1 ; turbidity ranged 0.03 3.23; dissolved oxygen ranged from $3.45-7.40 \mathrm{mg} / \mathrm{l}$; biochemical oxygen demand ranged from $1.20-4.32 \mathrm{mg} / 1$; chemical oxygen demand ranged from $2.50-5.21 \mathrm{mg} / 1$; Calcium ranged from $0.81-5.64 \mathrm{mg} / 1$; potassium ranged from $1.01-4.22 \mathrm{mg} / \mathrm{l}$; Nitrate ranged from $1.49-4.02 \mathrm{mg} / \mathrm{l}$; magnesium ranged from $0.13-2.20 \mathrm{mg} / \mathrm{l}$; phosphate ranged from $0.51-2.01 \mathrm{mg} / \mathrm{l}$. The water samples were all within the WHO limits apart from sample from Iyi Agbozu that had temperature of $32^{\circ} \mathrm{C}$.
\end{abstract}


Keywords: microbial, physicochemical characteristics, seasonal dynamics, eastern Nigeria

\section{Introduction}

Water is indispensably and intricately connected to life without which there is no life. This is the reason for which water must be given the necessary attention at all times. The supply of safe drinking water to all has therefore engaged the attention of many individual, groups, governmental organization and private (Wahab et al., 2012). Natural water is never absolutely pure, as it carries traces of other substances which bestow on it physical, chemical and bacteriological characteristics. The nature and amount of these substances called impurities vary with sources of the water (Oyhakilome et al., 2012). In developing countries including Nigeria, the majority of people live in rural areas. Water from rivers, streams, wells and more recently boreholes serve as the main sources of water for drinking and domestic use (Ibe and Okplenye, 2005). Conformation with physiochemical and microbiological standards is of special interest because of the capacity of water to spread diseases within a large population. A good knowledge of the chemical qualities of raw water is necessary so as to guide its suitability for use (Sunday and Innocent 2012). The presence of these biological and chemical parameters in drinking water affects the $\mathrm{pH}$, colour, salinity, dissolved oxygen, total solutes, alkalinity, hardness and conductivity of the water beyond WHO specified tolerable limits. This leads to various water borne diseases including diarrhea, cholera, typhoid fever, shigellosis, giardiasis, schistosomiasis, hepatitis and onchocerciasis (Akubuenyi et al., 2013).

\section{Materials and Methods}

\section{Study Area}

Uzuakoli is in Bende Local Government area, of Abia State and has a long history dating back to the time of the slave trade when its market, Agbo Agwu, was a major centre for slave exchange. It is located in the northern region of Abia State. Uzuakoli lies between Latitude 5.6333 and Longitude 7.5667. The community is made up of five villages, Agbozu, Amamba, Amankwo, Eluama and Ngwu, each of the villages have their streams and boreholes.

\section{Sample Collection}

The sample were collected twice a month for a period of six months, covering February, march, april for dry season and june, july and august for rainy season. Water samples were collected using sterile $500 \mathrm{ml}$ containers which were first washed and properly sterilized to avoid contamination. The stream water samples were collected by unscrewing the cap of the container and holding the container near its base in the hand and plunging its neck downwards below the surface. The containers were turned until neck points slightly upwards and mouth is directed towards the current. When the water fills the containers it was carefully removed and corked. In other to collect sample from borehole, cotton wool soaked in ethanol was used to disinfect the nozzle of the boreholes and then the tap was turned on to allow water to run for two minutes before sterile $500 \mathrm{ml}$ screw capped plastic containers were carefully uncapped and filled with water and recapped. The samples were labeled with code names for proper identification. Thereafter the water samples were transported to the laboratory for analysis within six hours of collection (Cheesbrough, 2010). 


\section{Ml Macrothink

\section{Enumeration of Total Heterotrophic Bacteria Count}

Samples of the stream water samples were serially diluted in ten folds. Total heterotrophic counts were determined using pour plate technique. The molten nutrient agar, were poured into the Petri dishes containing $1.0 \mathrm{~mL}$ of the dilution for the isolation of the total heterotrophic bacteria. They plates were swirled to mix thoroughly and the colony counts were taken after incubating the plates at room temperature for $48 \mathrm{~h}$ and preserved by sub-culturing the bacterial isolates into nutrient agar slants which were used for biochemical tests (APHA, 1998).

\section{Characterization and Identification of Bacterial}

Bacterial isolates were characterized and identified after studying the Gram reaction as well as cell morphology. Other tests performed were spore formation, motility, oxidase and catalase production, citrate utilization, oxidative/fermentation $(\mathrm{O} / \mathrm{F})$ utilization of glucose; indole and coagulase production, starch hydrolysis, sugar fermentation, methyl red-Voges Proskaur reaction and urease production. The tests were performed according to the methods of (Cheesbrough, 2010). Microbial identification was performed using the keys provided in the Bergeys Manual of Determinative Bacteriology (1994).

\section{Physicochemical Analysis}

The physicochemical parameters include temperature, $\mathrm{pH}$, dissolved oxygen (DO), turbidity, nitrate, phosphate, calcium, potassium, biochemical oxygen demand (BOD) and chemical oxygen demand (COD). The $\mathrm{pH}$ was measured in-situ using $\mathrm{pH}$ meter; the temperature was measured in situ using mercury in bulb thermometer in centigrade scale, turbidity was determined using spectrophotometric method. Potassium, magnesium, phosphate, nitrate, dissolved oxygen, Chemical oxygen demand and biochemical oxygen demand were determined by method of (ALPHA 1998).

\section{Results}

Figures 4.1 showed the seasonal variation of the total heterotrophic bacterial count. Table 4.1 showed the frequency of occurrence of bacteria. The physicochemical parameters are shown in table $4.2-4.3$. 


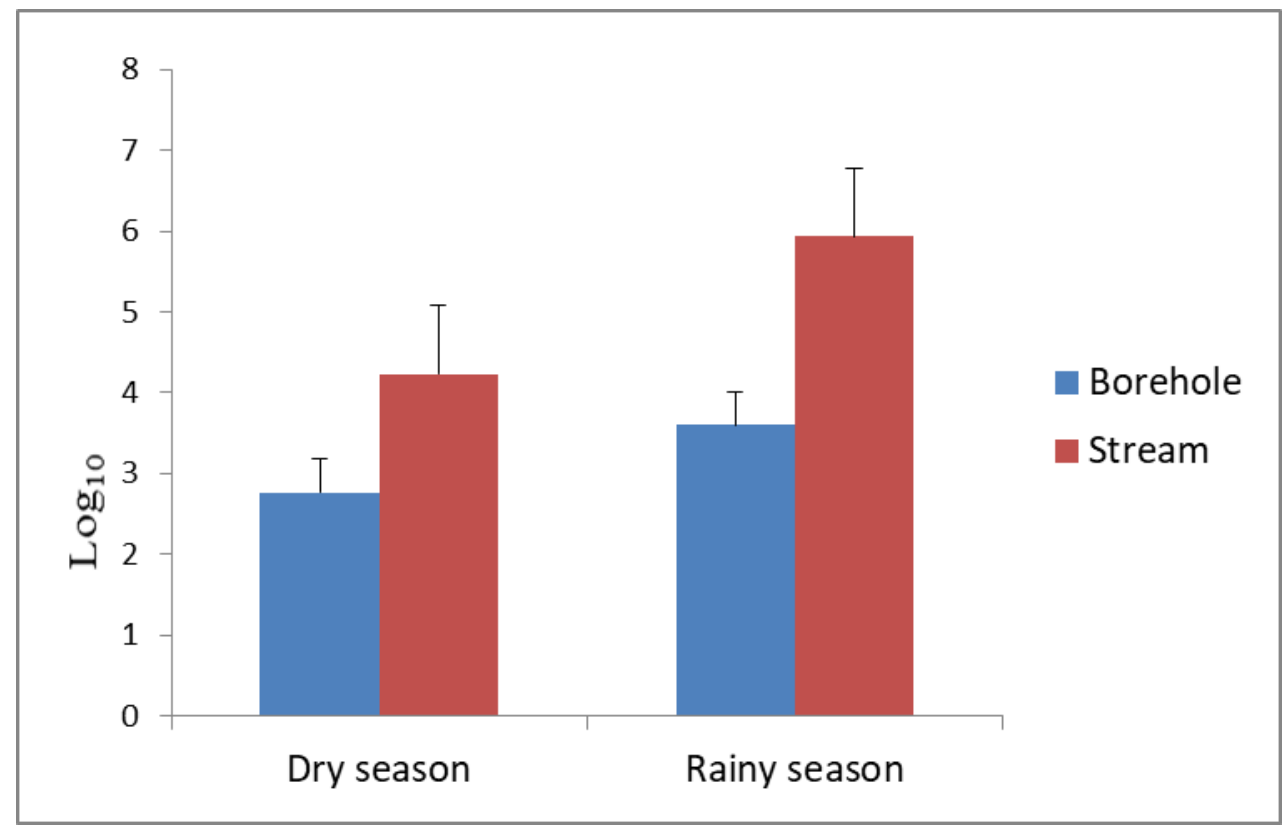

Figure 4.1. Mean Seasonal Heterotrophic Counts in Borehole and Stream Water Samples $(\mathrm{cfu} / m l)$

Table 4.1. Percentage (\%) occurrences of the bacterial isolates in water samples

\begin{tabular}{llll}
\hline Bacterial Isolates & $\begin{array}{l}\text { Isolates in borehole samples } \\
(\mathrm{n}=180)\end{array}$ & $\begin{array}{l}\text { Isolates in stream samples } \\
(\mathrm{n}=60)\end{array}$ \\
\hline Staphylococcus aureus & $113(63 \%)$ & $51(85 \%)$ & \\
Streptococcus sp & $83(46 \%)$ & $32(53 \%)$ & \\
Escherichia coli & $29(16 \%)$ & $32(53 \%)$ & \\
Salmonella sp & $0(0 \%)$ & $24(40 \%)$ \\
Pseudomonas aeruginosa & $89(49 \%)$ & $57(95 \%)$ & \\
Enterebacter aerogenes & $59(33 \%)$ & $38(63 \%)$ & \\
Proteus sp & $94(52 \%)$ & $58(97 \%)$ & \\
\hline
\end{tabular}


Table 4.2. Physicochemical parameters of borehole water samples during dry and rainy season

\begin{tabular}{|c|c|c|c|c|c|c|c|c|c|c|c|}
\hline \multirow[b]{2}{*}{ Parameters } & \multicolumn{6}{|c|}{ Mean of Dry season } & \multicolumn{5}{|c|}{ Mean of Rainy } \\
\hline & 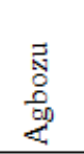 & $\begin{array}{l}\stackrel{\Xi}{0} \\
\stackrel{\Xi}{\Xi} \\
\Xi \\
\Xi\end{array}$ & $\begin{array}{l}\stackrel{8}{\Xi} \\
\frac{\Xi}{\Xi} \\
\Xi \\
\Xi\end{array}$ & $\underset{\stackrel{\Xi \Xi \Xi}{\Xi}}{\stackrel{\Xi}{\Xi}}$ & $\begin{array}{c}\overrightarrow{3} \\
z^{\prime}\end{array}$ & \begin{tabular}{l}
$\overrightarrow{7}$ \\
0 \\
0 \\
\multirow{2}{0}{}
\end{tabular} & 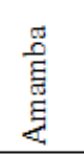 & $\begin{array}{l}\stackrel{\circ}{\xi} \\
\frac{3}{E} \\
\Xi \\
\Xi\end{array}$ & 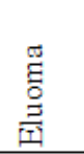 & $\begin{array}{l}\vec{B} \\
\vec{Z} \\
Z\end{array}$ & 芯惫导 \\
\hline $\mathrm{pH}$ & 5.5 & 6.1 & 6.7 & 5.5 & 5.9 & 6.2 & 5.8 & 6.3 & 6.6 & 7.8 & $6.5-8.5$ \\
\hline Temp $\left({ }^{\circ} \mathrm{C}\right)$ & 27 & 28 & 29 & 28 & 30 & 25 & 25 & 26 & 28 & 29 & $25^{\circ} \mathrm{C}-30^{\circ} \mathrm{C}$ \\
\hline Turbidity & 0.04 & 0.04 & 0.03 & 0.06 & 0.06 & 0.36 & 2.21 & 1.68 & 2.21 & 1.10 & 5 \\
\hline $\mathrm{DO}(\mathrm{mg} / \mathrm{l})$ & 4.03 & 4.92 & 3.82 & 5.01 & 3.45 & 6.43 & 6.01 & 7.31 & 7.31 & 7.40 & 14 \\
\hline $\mathrm{BOD}(\mathrm{mg} / \mathrm{l})$ & 2.35 & 2.39 & 2.31 & 1.20 & 2.42 & 2.40 & 2.89 & 3.61 & 3.81 & 3.90 & $<4$ \\
\hline $\mathrm{COD}(\mathrm{mg} / \mathrm{)})$ & 3.26 & 3.05 & 3.26 & 2.50 & 3.01 & 3.22 & 3.50 & 3.01 & 2.92 & 3.33 & $<10$ \\
\hline $\mathrm{Ca}^{2+}(\mathrm{mg} / 1)$ & 0.81 & 2.53 & 3.50 & 1.25 & 2.53 & 2.41 & 2.22 & 2.41 & 0.82 & 3.19 & 50 \\
\hline $\mathrm{K}^{+}(\mathrm{mg} /)$ & 3.43 & 3.41 & 2.45 & 3.43 & 2.56 & 4.22 & 2.71 & 3.25 & 1.01 & 3.25 & - \\
\hline $\mathrm{P}(\mathrm{mg} / \mathrm{l})$ & 0.51 & 1.22 & 1.49 & 0.62 & 2.01 & 0.23 & 0.11 & 1.01 & 1.88 & 1.43 & - \\
\hline $\mathrm{Mg}^{2+}(\mathrm{mg} /)$ & 0.22 & 0.71 & 1.30 & 1.23 & 1.23 & 0.14 & 0.62 & 1.13 & 1.14 & 1.14 & 30 \\
\hline $\mathrm{NO}_{3}(\mathrm{mg} / 1)$ & 3.96 & 3.66 & 3.02 & 3.28 & 3.34 & 2.45 & 4.02 & 3.20 & 3.21 & 4.02 & 10 \\
\hline
\end{tabular}

Table 4.3. Physicochemical parameters of stream water samples during dry and rainy season

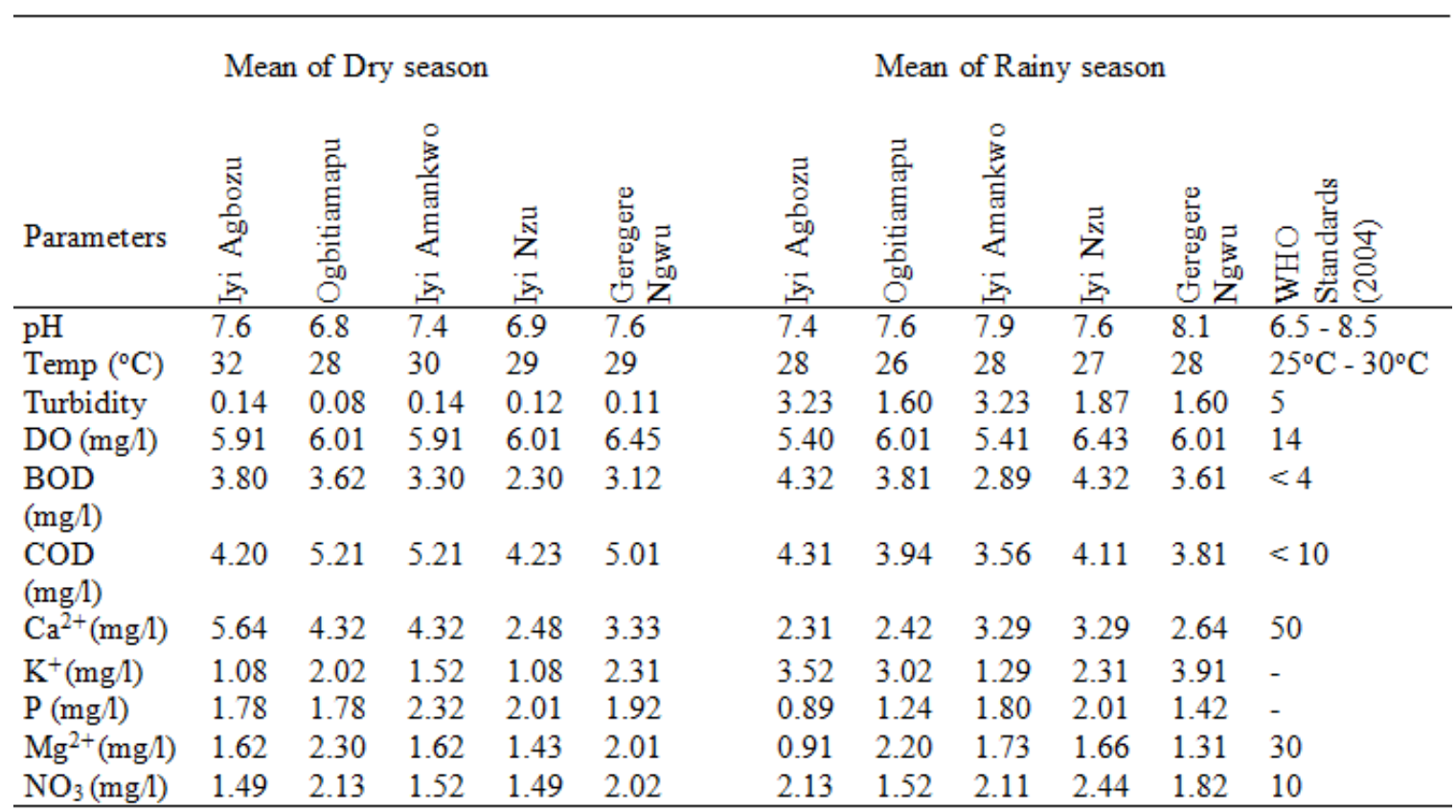

\section{Discussion}

The microbiological analysis reveals that the microbial load varied from dry season rainy season across the streams and boreholes. The borehole waters had the least microbial counts when compared to the stream waters. The highest microbial counts were recorded in streams during the rainy season which could be due to runoffs, domestic and human activities. However the bacterial load decreased downstream and this could be attributed to possible self-purification and dilution of the pollutants (Eze et al., 2013). The isolated bacteria were Staphylococcus aureus, Pseudomonas aeruginosa, Proteus sp, Streptococcus sp, Enterobacter aerogenes, Escherichia coli and Salmonella sp. The borehole samples are free of Salmonella 
$s p$. unlike the streams samples. These organisms are important human pathogens associated with a variety of infectious diseases such as gastroenteritis, typhoid fever, dysentery, cholera and urinary tract infections etc. Their presence raises serious public health concern because they are known causative agents of many water borne diseases and indicates that these water sources are not potable (Akubuenyi et al., 2013). The presence of Escherichia coli which is the most common indicator of faecal pollution in a water sample is an indication of the presence of enteric pathogens. This confirms the result of an earlier study by Okezie and Nwachukwu (2018), indicating that most boreholes and streams are heavily contaminated with faecal matter.

The physicochemical parameters analyzed were all within the WHO limit for drinking water except for the temperature and BOD for the streams. The stream water samples had $\mathrm{pH}$ within the WHO permissible limits of 6.5 - 8.5 while borehole water samples from Agbozu, Eluoma and $\mathrm{Ngwu}$ had $\mathrm{pH}$ values below the WHO permissible limits. The low $\mathrm{pH}$ values obtained from the borehole samples could be attributed to dissolved mineral salts in water (Shittu et al., 2008). The temperature of the samples differed significantly. The highest was observed in the stream samples from $26^{\circ} \mathrm{C}-32^{\circ} \mathrm{C}$ and lowest in the borehole samples from $25^{\circ} \mathrm{C}-30^{\circ} \mathrm{C}$. However, temperature of a water body is affected by a number of factors such as climate of the area, extent of shade from direct sunlight and depth of water. The drop in temperature across the months in this study could be as a result of increased rainfall, inflow of runoffs into water bodies and cooled weather (Ekhaise and Anyansi, 2005). All the samples had turbidity values within the WHO permissible limits. Turbidity could be caused due to runoff and human activities around the streams. Excessive turbidity in water causes problems with water purification process (John et al., 2008).

Dissolved oxygen is one of the important and critical characteristics of water quality assessment. During the dry season the stream had more dissolve oxygen values than the boreholes while during the rainy season the boreholes had more values than the stream. The low values observed may be as a result of the increased runoffs of agricultural wastes and industrial effluents discharged into the drains that place high demand on the dissolve oxygen (Shittu et al., 2008).

Biochemical oxygen demand (BOD) measures the amount of dissolved oxygen needed by microorganisms to break down organic matter present in a water samples over a specific time (Anake et al., 2013). According to Oluyemi et al. (2010) BOD values less than $4 \mathrm{mg} / \mathrm{l}$ suggests that the water is less polluted by organic matter and could support aquatic life. The BOD for the borehole and stream samples is below $4 \mathrm{mg} / \mathrm{l}$ apart from BOD from Iyi Agbozu and Iyi Nzu. The stream water samples had more BOD values than the borehole samples. However, comparing the BOD value for dry season and rainy season, the rainy season had the highest BOD values.

Chemical Oxygen Demand value for the borehole samples is low compared to the stream samples. The borehole and stream water samples have COD values below $10 \mathrm{mg} / \mathrm{l}$.

Calcium ions measured in the borehole and stream water samples were within the WHO permissible limit. Excess calcium in water could causes hardness of water. Calcium is 
essential and helps in bone formation. It is commonly present in all water bodies where it usually comes from the leaching of rocks (Akubuenyi et al., 2013).

Phosphate, Potassium and Nitrate were all within the WHO permissible limits for drinking water. Phosphates and nitrates are important ingredients in plant blooms and eutrophication of streams (WHO, 2006). Nitrate in concentration greater than $45 \mathrm{mg} / \mathrm{l}$ is undesirable in domestic water supplies because of the potential toxic effect on young infants. Methemoglobinemia is a disease caused by nitrate, which occurs when it is converted to nitrite in the intestines. Nitrate cannot be removed from water by boiling but must be treated by distillation (Sunday and Innocent, 2012).

\section{Conclusion}

There is seasonal variation in the microbial load of the water samples especially, during the rainy season which could be as a result of runoffs and human activities. This may lead to spread of diseases.

\section{References}

Akubuenyi, F. C., Uttah, E. C., \& Enyiidoh, K. H. (2013). Microbiological and Physicochemical Assessment of major sources of water for Domestic Uses in Calabar Metropolis, Cross River State, Nigeria.Transnational Journal of Science and Technology, 3(2) $1-14$.

Anake, W. U., Ehi-eromosele, C. O., Adeniyi, I. O., \& Taiwo, O. S. (2013). Physico-chemical and Microbial Assessment of Different Water Sources in Ota, Ogun State, Nigeria. International Journal of Current Research, 5(7), 1797-1801.

APHA (1998). Standard methods for examination of water and waste water, 20th Ed. American Public Health Association. New York. pp 81-85.

Bergey's Manual of Determinative Bacteriology (1994). $9^{\text {th }}$ Edition, Holt, J. D., Williams and Wilkins, Baltimore, 783-788.

Cheesbrough, M. (2002). District Laboratory Practice inTropical Countries Part 2. Cambridge University Press, United Kingdom, pp. 143-154.

Ekhaise, F. O., \& Anyansi, C. C. (2005). Influence of brewery effluent discharge on the microbiological and physicochemical quality of Ikpoba river, Nigeria. Afri. J. Biotechnol., 4(10), 1062-1065.

Eze, V. C., Edward, K. C., \& Shedrack, I. F. (2013). Microbiological and Physicochemical Characteristics of Iyi-Nna Stream, Umuariaga, Ikwano L.G.A, Abia State, Nigeria. Journal of Pharmacy and Biological Sciences, 8(2), 44-49. https://doi.org/10.9790/3008-0824449

Ibe, S. N., \& Okplenye, J. I. (2005). Bacteriological Analysis of Borehole Water in Uli, Nigeria. African Journal of Applied Zoology and Environmental Biology, (7), 116-119.

John, K. N., Orish, E. O., \& Linus, O. E. (2008). Some Physicochemical Parameters of Potable Water Supply in Warri, Niger Delta Area of Nigeria. Science Research and Essence, 
$3(11), 547-551$.

Okezie, O., \& Nwachukwu, E. (2018). Microbiological Evaluation of Drinking Water Supplies in Uzuakoli, Bende L.G.A. of Abia State, Nigeria. Advances in Applied Science Research, 9(2), 69-74.

Oluyemi, E. A., Adekunle, A. S., Adenuga, A. A., \& Makinde, W. O. (2010). Physico-chemical Properties and Heavy Metal Content of Water Sources in Ifane North Local Government Area of Osun State, Nigeria. African Journal of Environmental Science and Technology, 4(10), 691-697.

Oyhakilome, G. I., Aiyesanmi, A. F., \& Akharaiyi, F. C. (2012). Water Quality Assessment of the Owena Multi-Purpose Dam, Ondo State, Southwestern Nigeria. Journal of Environmental Protection, (3), 14-25.

Shittu, O. B., Olaitan, J. O., \& Amusa, T. S. (2008). Physicochemical and Bacteriological Analysis of Water Used for Drinking and Swimming Purposes in Abeokuta, Nigeria. African Journal of Biomedical Research, 2, 285-290.

Sunday, O. E., \& Innocent, C. M. (2012). Physicochemical and Microbiological Analysis Of Water Bodies in Uturu, Abia State, Nigeria. Asian Journal of Natural and Applied Sciences, 1(4), 1-8.

Wahab, M. K. A., Ganiyu, O. T., Olabiran, A. D., \& Ojo, S. D. (2012). Prevalence of Pathogenic Microorganism in Osun Osogbo sacred river water. International Journal of Agri Science, 2(10), 935-941.

WHO (2006). Guidelines for Drinking Water Quality. First Addendum to $3^{\text {rd }}$ Edition. Vol. 1. Geneva.

\section{Copyright Disclaimer}

Copyright for this article is retained by the author(s), with first publication rights granted to the journal.

This is an open-access article distributed under the terms and conditions of the Creative Commons Attribution license (http://creativecommons.org/licenses/by/3.0/). 